\title{
Erratum to: An Evolutionary Perspective on Water Governance: From Understanding to Transformation
}

\author{
Claudia Pahl-Wostl ${ }^{1}$
}

Published online: 19 June 2017

(C) Springer Science+Business Media B.V. 2017

\section{Erratum to: Water Resour Manage}

\section{DOI: 10.1007/s11269-017-1727-1}

Unfortunately, the article title was incorrectly captured in the published online paper.

The article title should have been An Evolutionary Perspective on Water Governance: From Understanding to Transformation instead of Introduction - Water Governance an Emerging Field of Scientific Scholarship.

The corrected article title is shown above. The original article was corrected.

The online version of the original article can be found at http://dx.doi.org/10.1007/s11269-017-1727-1

Claudia Pahl-Wostl

cpahlwos@uni-osnabrueck.de

1 Institute of Environmental Systems Research, University of Osnabrück, Osnabrück, Lower Saxony, Germany 